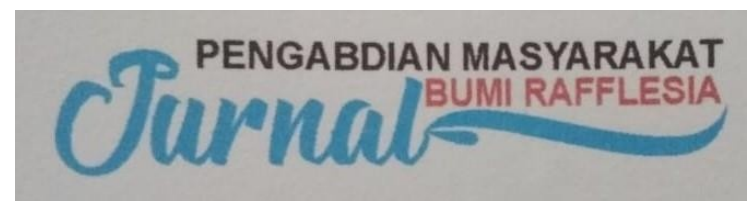

\title{
PENINGKATAN KESEJAHTERAAN MASYARAKAT MELALUI PENGEMBANGAN POTENSI LOKAL DI DESA SUKASARI KECAMATAN PERIUKAN KABUPATEN SELUMA PROVINSI BENGKULU
}

\author{
Zahrah Indah Ferina, Kresnawati, Neri Susanti, Wagini, Yun Fitriano \\ Program Studi Akuntansi Fakultas Ekonomi Universitas Dehasen Bengkulu \\ *Corresponding author : zahrahindah@unived.ac.id
}

\begin{abstract}
ABSTRAK
Indonesia merupakan Negara agraris, dimana penduduknya sebagian besar merupakan petani. Indonesia dianugrahi Sumber Daya Alam yang sangat berlimpah akan tetapi kondisi yang sangat menguntungkan itu berbanding terbalik dengan keadaan Indonesia sekarang ini. Pertanian memiliki produktifitas tenaga kerja yang rendah dan juga didominasi oleh tenaga kerja tidak dibayar (pekerja keluarga), sehingga pertumbuhan yang terjadi pada lapangan usaha ini belum mampu memberikan manfaat banyak terhadap kesejahteraan masyarakat (petani). Hal ini dapat kita lihat di desa Sukasari kecamatan Periukan kabupaten Seluma. Potensi pertaniannya belum dimaksimalkan dengan baik, maka kami team pengabdian dari Fakultas Ekonomi Univeristas Dehasen membagi informasi dan ilmu bagaimana memaksimalkan potensi alam dari desa SUkasari ini. Diharapakan pengabdian ini dapat memberikan kontribusi kepada warga sekitar yang diberikan materi tentang kewirausahaan dan pemaksimalan potensi desa. Tentu desa Sukasari memiliki potensi yang besar untuk memaksimalkan hasil dari Sumber Daya Manusianya.yaitu dengan memanfaatkan potensi kelapa dan serai.
\end{abstract}

\section{PENDAHULUAN}

Pertanian dan pedesaan di Indonesia merupakan satu kesatuan yang tidak dapat dipisahkan, hal ini dikarenakan Indonesia merupakannegara agraris. Negara agraris merupakan Negara yang penduduknya sebagian besar berprofesi sebagai petani. Negara ini diuntungkan karena kondisi sumber daya alam yang berlimpah. Realita sumber daya alam yang berlimpah seharusnya menjadikan Negara ini menjadi Negara yang maju, akan tetapi sumberdaya manusia untuk mengolah hasil petanian tersebut masih sangat kurang.
Konsep Malthus yang menyatakan bahwa pertumbuhan pangan bagaikan deret hitung dan pertumbuhan penduduk bagai deret ukur, nampaknya mendapat momen tumnya sekarang. Bangsa Indonesia dengan pertumbuhan penduduk positif, apabila tidak disertai dengan kenaikan produksi pangan, maka akan berpeluang menghadapi persoalan pemenuhan kebutuhan pangan penduduknya di masa datang. Kebutuhan pangan senantiasa meningkat seiring dengan peningkatan jumlah penduduk. Di sisi pemenuhannya, tidak semua kebutuhan 
pangan dapat dipenuhi, karena kapasitas produksi dan distribusi pangan semakin terbatas. Hal ini menyebabkan ketidakstabilan pangan antara kebutuhan dan pemenuhannya secara nasional (Purwaningsih, 2017)

Berdasarkan UU No. 6 tahun 2014 tentang Desa, Desa adalah desa dan desa adat atau yang disebut dengan nama lain, selanjutnya disebut Desa, adalah kesatuan masyarakat hukum yang memiliki batas wilayah yang berwenang untuk mengatur dan mengurus urusan pemerintahan, kepentingan masyarakat setempat berdasarkan prakarsa masyarakat, hak asal usul, dan/atau hak tradisional yang diakui dan dihormati dalam sistem pemerintahan Negara Kesatuan Republik Indonesia. Berdasarkan definisi ini dapat disimpulkan bahwa desa dapat menjalankan otonominya sendiri yaitu menjalankan pemerintahannya berdasarkan hak asal usul dan adat istiadatnya, atau yang dapat disebut dengan otonomi asli. Selain pengaturan tentang otonomi desa, UU desa juga menjelaskan tentang kewenangan desa yang salah satunya adalah kewenangan dalam bidang pembangunan desa. Kewenangan pembangunan desa ini termuat dalam UU No. 6 tahun 2014 Bab IV pasal 18 bahwa: "Kewenangan dibidang penyelenggaraan pemerintahan desa, pelaksanaan pembangunan desa, pembinaan kemasyarakatan desa, dan pemberdayaan masyarakat desa berdasarkan prakarsa masyarakat, hak asal usul, dan adat istiadat desa". Lebih lanjut lagi dijelaskan bahwa kewenangan desa meliputi: Pertama, Kewenangan berdasarkan hak asal usul.

$$
\text { Menurut Sukrino }
$$

Kewenangan asal usul desa mencakup pengelolaan asset desa, seperti pengelolaan sumber daya alam. Pertama, dengan adanya kewenangan ini maka desa dapat melakukan pembangunan desanya sesuai dengan potensi yang ada. Kedua, kewenangan lokal berskala Desa. Ketiga, kewenangan yang ditugaskan oleh Pemerintah, Pemerintah Daerah Provinsi, atau Pemerintah Daerah Kabupaten/Kota. Keempat, kewenangan lain yang ditugaskan oleh Pemerintah, Pemerintah Daerah Provinsi, atau Pemerintah Daerah Kabupaten/Kota sesuai dengan ketentuan peraturan perundangundangan. Sesuai UndangUndang No. 6 Tahun 2014 Tentang Desa pasal 78 poin (1) menjelaskan bahwa potensi ekonomi lokal desa menjadi syarat adanya pembangunan desa yang bertujuan meningkatkan kesejahteraan masyarakat desa dan kualitas hidup manusia. Pembangunan desa yang sesuai dengan potensi dan sumber daya lokal yang dimiliki dapat dijadikan sebagai icon bagi desa tersebut. Berdasarkan UU No. 6 tahun 2014 tentang Desa Bab I Pasal I, bahwa "Pembangunan Desa adalah upaya peningkatan kualitas hidup dan kehidupan untuk sebesar-besarnya kesejahteraan masyarakat desaPertumbuhan ekonomi merupakan salah satu indikator yang amat penting dalam analisis pembangunan ekonomi suatu wilayah. Pertumbuhan ekonomi menunjukkan aktivitas perekonomian menghasilkan tambahan pendapatan masyarakat pada suatu periode tertentu. Mengingat pada dasarnya aktivitas perekonomian adalah suatu proses penggunaan faktor produksi untuk menghasilkan output, maka proses ini pada akhirnya akan menghasilkan balas jasa terhadap faktor produksi yang dimiliki oleh masyarakat. Dengan adanya pertumbuhan ekonomi, diharapkan pendapatan masyarakat sebagai pemilik faktor produksi akan meningkat.

Pembangunan yang berlangsung saat ini belum berhasil mengangkat pertanian kepada posisi yang seharusnya. Kesenjangan kesejahteraan petani dibandingkan dengan pekerja disektor lain masih sangat terasa. 
Produk pertanian di Indonesia masih kurang daya saingnya terhadap negara lainnya.Ketepurukan dan tidak berkembangnya sektor pertanian ini memiliki dampak luas dan dalam bagi pembangunan ekonomi dan pembangunan Indonesia secara keseluruhan. Menurut Harianto (2007) dampak negatif nyata dari terpuruknya pertanian adalah: 1) tingkat kemiskinan meningkat, 2) ketahanan pangan rendah, 3) ketergantungan pada pangan luar negeri menjadi tinggi.4) industrialisasi yang terjadi sangat tergantung pada factor produksi atau bahan baku impor, 5) pengangguran dipedesaan tinggi, 6)stabilitas keamanan rendah, 7) mutu kehidupan dipedesaan merosot, 8) kualitas sumberdaya manusia merosot, 9) kualitas lingkungan dan sumber daya alam merosot, 10) kemampuan atau daya saing bangsa dan negara rendah.

Dalam Undang- Undang No. 6 Tahun 2014 Tentang desa pembangunan kawasan perdesaan merupakan perpaduan pembangunan antar desa dalam 1 (kabupaten/ kota). Pembangunan kawasan perdesaan dilakukan oleh pemerintah, pemerintah daerah provinsi dan pemerintah daerah kabupaten / kota dan pihak ketiga yang terkait dengan aset desa dan tata ruangan desa wajib melibatkan pemerintah desa (pasal 84 ayat 1).Dalam RPJMN 20152019 arah kebijakan dan strategi pembangunan desa dan kawasan perdesaan adalah (1) Pemenuhan Standar Pelayanan Minimum Desa sesuai dengan kondisi

\section{METODE KEGIATAN}

Kegiatan ini di lalukan di desa Sukasari Kec. Air Periukan Kab. Seluma Provinsi Bengkulu pada hari Jumat tanggal 28 September 2018 yang diikuti oleh para perangkat desa, tokoh agama, tokoh masyarakat, Aparatur Sipil Negara Desa Sukasari dan warga desa. Adapun metode yang digunakan dalam pemecahan geografisnya, (2) Penanggulangan kemiskinan dan pengembangan usaha ekonomi masyarakat Desa, Pembangunan sumber daya manusia, peningkatan keberdayaan, dan pembentukan modal sosial budaya masyarakat Desa, (4) pengelolaan sumber daya alam dan lingkungan hidup berkelanjutan, serta penataan ruang kawasan perdesaan, dan (5) pengembangan ekonomi kawasan perdesaan untuk mendorong keterkaitan desa-kota.

Adapun desa yang akan dituju disini adalah Desa Sukasari kecamatan Periukankabupaten seluma. Potensi ekonomi Kabupaten Seluma pada umumnya dapat dilihat dari struktur perekonomiannya yang didasari pada PDRB atas dasar harga berlaku, dimana perekonomian Kabupaten Seluma didominasi oleh lapangan usaha pertanian dengan peranan sebesar 53,65 persen. Meskipun peran lapangan usaha ini masih dominan, namun jika dilihat dari trennya tampak gejalapenurunan peranan pertanian setiap tahun meskipun kecil. Berdasarkan informasi yang telah diperoleh dari masyarakat Desa Sukasari bahwa pertanian di daerah tersebut masih sangat kurang dalam pengelolaannya, kualitas dan bagaimana memasarkannya. Adapun potensi dari pertanian desa Sukasari merupakan tanaman kelapa. Tanaman kelapa merupakan tanaman yang disetiap bagiannyamemiliki manfaat, dimulai dari buah, batang, daun, dan akarnya.

permasalahan yaitu dengan memberikan pelatihan kewirausahaan. Diberikan materi tentang apa itu kewirausahaan dan dijelaskan pentingnya kewirausahaan, dan bagaimana melakukan kewirausahaan agar di sokong dana oleh pemerintah guna meningkatkan profit keluarga dan menganalisis potensi yang bisa ditingkatkan 
oleh daerah tersebut. Selanjutnya melakukan pendampingan pada masyarakat untuk mengelola potensi yang ada, sehingga kegiatan ini benar-benar tepat sasaran yaitu memaksimalkan potensi desa Suksari. Harapan dari kegiatan ini adalah tercapainya

\section{HASIL DAN PEMBAHASAN}

\section{a. Kegiatan Lokakarya Awal}

Kegiatan ini dimulai dari jam 9.00 WIB pagi sampai jam 15.00 WIB di Desa Sukasari Kec. Air Periukan Kab. Seluma Provinsi Bengkulu. Kegiatan awal melalukan seminar telaah potensi alam di lingkungan Desa Sukasari. Disini kami menjelaskan letak geografis daerah Seluma, Menurut Pusat Data dan Informasi (2016) secara administratif Kabupaten Seluma dibentuk berdasarkan Undang-Undang Nomor 3 Tahun 2003 tentang Pembentukan Kabupaten Muko-Muko, Kabupaten Seluma, dan Kabupaten Kaur dengan luas 2.400,44 $\mathrm{km} 2$ atau 12,13\% dari luas Provinsi Bengkulu dan wilayah laut seluas 1.728,02 $\mathrm{km}^{2}$ sehingga total keseluruhan luas Kabupaten Seluma adalah 4.128,46 $\mathrm{km}^{2}$.Secara geografis Kabupaten Seluma terletak di pesisir barat Sumatera sebelah selatan. Kabupaten Seluma berada di koordinat 03o 49' 55,66" - 04o 21' 40,22" LS dan 1010 17,27' 57' - 102o 59' 40,54" BT. Iklim Wilayah Kabupaten Seluma memiliki sifat iklim tropis dengan dua musim yaitu musim kemarau dan musim penghujan dengan curah hujan tahunan pada umumnya tinggi. Kabupaten Seluma beriklim tropis dengan suhu udara rata-rata maksimum antara $31^{\circ} \mathrm{C}-33^{\circ} \mathrm{C}$ dan rata-rata suhu minimum antara $22^{\circ} \mathrm{C}-23^{\circ} \mathrm{C}$, sedangkan kelembaban rata-rata antara $80 \%$ - 88\% Rata-rata curah hujan di Kabupaten Seluma pada tahun 2014 sebesar 234,73 $\mathrm{mm}$, dimana rata-rata curah hujan terbesar terjadi pada bulan November. Sedangkan bulan dengan jumlah rata-rata curah hujan kegiatan seminar ini dengan hasil yang maksimal, dan diharapkan tim pengabdian dapat diterima dengan baik sehingga kerjasama ini dapat berjalan dengan berkelanjutan.

Berikut ini dokumentasi dari kegiatan:

terkecil yaitu pada bulan Juni. Curah hujan tertinggi tercatat pada bulan November di pos Rimbo Kedui sebesar $677 \mathrm{~mm}$. Sedangkan curah hujan terendah tercatat pada bulan Juni di pos Air Periukan sebesar 0 mm.dan topografi kabupaten Seluma Bengkulu Selatan.

Selanjutnya membahas tentang produk unggulan Seluma, Bengkulu Utara, dan selanjutnya membahasa Desa Sukasari yang memiliki potensi hasil kelapa yang cukup besar, dan setalah itu kami telaah bagaimana kelapa ini dapat dimanfaatkan setiap komponennya untuk di proses lebih lanjut seperti minyak kelapa, selanjutnya kami membahas bagaimana produk akan dikemas dengan baik sehingga minyak tersebut dapat dipasarkan keluar daerah, selanjutnya kami membahas tentang bagaimana minyak kelapa tersebut dapat dipasarkan, dan metode-metode apa yang baik digunakan untuk memasarkan hasil dari proses penyulingan minyak kelapa. Selanjutnya kami membahas potensi lain dari desa tersebut yaitu pola pengembangkanserai. Serai mempunyai perawakan berupa rumput-rumputan tegak, menahun dan mempunyai perakaran yang sangat dalam dan kuat. Batangnya dapat tegak ataupun condong, membentuk rumpun, pendek, masif, bulat dan sering kali di bawah buku-bukunya berlilin, penampang lintang batang berwarna merah. Daunnya merupakan daun tunggal, lengkap dan pelepah daunnya silindris, gundul, seringkali bagian permukaan dalam berwarna merah, 
ujung berlidah (ligula), helaian, lebih dari separuh menggantung, remasan berbau aromatik. Susunan bunganya malai atau bulir majemuk, bertangkai atau duduk, berdaun pelindung nyata, biasanya berwarna sama umumnya putih. Daun pelindung bermetamorfosis menjadi gluma steril dan fertil (pendukung bunga). Kelopak bunga 5 bermetamorfosis menjadi bagian palea (2 unit) dan lemma atau sekam (1 unit), mahkota bermetamorfosis menjadi 2 kelenjar lodikula, berfungsi untuk membuka bunga di pagi hari. Benang sari berjumlah 3-

\section{b. Menelaah Permasalahan}

Pembangunan pedesaan ini harus dilakukan secara berkelanjutan, bersinergi dengan pemerintah, dan berintegrasi. Sehingga perlu kita melakukan telaah permasalahan yang ada. Setiap potensi yang ada diharapkan dapat dikembangkan secara optimal. Menurut Harianto (2007) unsur-unsur pertanian pokok adalah 1) petani dan keluarga, 2) Sumber Daya Alam (SDA), 3) teknologi, 4) lingkungan sosial budaya. Unsur-unsur pertanian ini harus semuanya terpenuhi guna menghasilkan hasil yang sesuai dengan harapan kita.

Menurut Dimyati (2007), permasalahan yang masih melekat pada sosok petani di Indonesia adalah: 1. Masih minimnya wawasan dan pengetahuan petani terhadap masalah manajemen produksi maupun jaringan pemasaran. 2. Belum terlibatnya secara utuh petani dalam kegiatan agribisnis. Aktivitas petani masih terfokus pada kegiatan produksi (on farm). 3. Peran dan fungsi kelembagaan petani sebagai wadah organisasi petani belum berjalan secara optimal. Untuk mengatasi permasalahan di atas perlu melakukan upaya pengembangan, pemberdayaan, dan penguatan kelembagaan petani (seperti: kelompoktani, lembaga tenaga kerja, kelembagaan penyedia input, kelembagaan
6, membuka secara memanjang, kepala putik sepasang berbentuk bulu dengan perpanjangan berbentuk jambul. Buahnya berupa buah padi, memanjang, pipih dorso ventral, embrio separo bagian biji (Sudarsono, dkk., 2002).Minyak serai ini diharapkan dapat memberikan potensi pendapatan bagi masyarakat desa Sukasari. Selanjutnya masuk kemateri kewirausahaan untuk potensi bisnis lainnya tadi yaitu pemasaran produk hasil olahan Serai.

output, kelembagaan penyuluh, dan kelembagaan permodalan) dan diharapkan dapat melindungi bargaining position petani. Tindakan perlindungan sebagai keberpihakan pada petani tersebut, baik sebagai produsen maupun penikmat hasil jerih payah usahatani mereka terutama diwujudkan melalui tingkat harga output yang layak dan menguntungkan petani. Dengan demikian, penguatan dan pemberdayaan kelembagaan tersebut juga untuk menghasilkan pencapaian kesinambungan dan keberlanjutan daya dukung SDA dan berbagai usaha untuk menopang dan menunjang aktivitas kehidupan pembangunan pertanian di pedesaan.

Permasalahan selanjutnya yaitu distribusi Pangan. Distribusi pangan adalah kegiatan menyalurkan bahan pangan dari point of production (petani produsen) kepada point of consumption (konsumen akhir). Distribusi tidak hanya menyangkut distribusi pangan di dalam negeri namun juga menyangkut perdagangan internasional dalam suatu sistem harga yang terintegrasi secara tepat (Soetrisno, 2005). Dengan demikian perlu dibuat pola distribusi pangan yang menjamin seluruh rumah tangga dapat memperoleh pangan dalam jumlah yang

114 www.jurnal.umb.ac.id 
cukup sepanjang waktu dengan harga yang terjangkau. Permasalahan dalam distribusi pangan (Nainggolan, 2006): - Prasarana distribusi darat dan antar pulau yang diperlukan untuk menjangkau seluruh wilayah konsumen belum memadai, sehingga wilayah terpencil masih mengalami keterbatasan pasokan pangan pada waktu-waktu tertentu. Keadaan ini menghambat aksesibilitas masyarakat terhadap pangan, baik secara fisik, namun juga secara ekonomi, karena kelangkaan pasokan akan memicu kenaikan harga dan mengurangi daya beli masyarakat. • Kelembagaan pemasaran belum mampu berperan, baik sebagai penyangga kestabilan distribusi maupun harga pangan. Pada masa panen, pasokan pangan berlimpah ke pasar sehingga menekan harga produk pertanian dan mengurangi keuntungan usahatani. Sebaliknya pada masa paceklik atau masa

\section{c. Pengembangan Potensi Wilayah}

Desa Sukasari ini memili potensi kelapa yang cukup banyak. Selain kelapa desa Sukasari juga menanam batang serai untuk dijadikan minuman. Beberapa wilayah budidaya serai harus ditingkatkan.Penataan ruang wilayah juga harus dilakukan. Penataan ruang wilayah Desa bertujuan untuk mewujudkan Kabupaten Seluma yang maju, mandiri, aman, adil dan sejahtera serta perekonomian rakyat berdaya saing tinggiUntuk mencapai tujuan tersebut ditetapkan langkah sebagai berikut: 1 . Pengembangan organisasi ruang wilayah

\section{PENUTUPAN}

\section{Kesimpulan}

1. kegiatan seminar pertama memberikan materi tentang apa itu kewirausahaan, manfaat kewirausahaan dan bagaiman untuk dimana panen tidak berhasil, harga meningkat dengan tajam, sehingga mengurangi aksesibilitas masyarakat terhadap pangan. - Bervariasinya kemampuan produksi antar wilayah dan antar musim menuntut kecermatan dalam mengelola system distribusi pangan, agar pangan tersedia sepanjang waktu di seluruh wilayah konsumen. - Keamanan jalur distribusi dan adanya pungutan sepanjang jalur distribusi dan pemasaran, mengakibatkan biaya distribusi yang tinggi pada berbagai produk pangan.

Untuk Desa Sukasari ini hanya memiki satu atau dua hasil pertanian sehingga hasil yang didapatkan tidak maksimal dalam hal mengembangkan hasil pertanian guna menghasilkan pendapatan yang lebih pada saat ini. Sumber daya alam yang tersedia hendaknya dimaksimalkan dalam mengelolanya.

desa yang efisien melalui susunan pusat kegiatan yang berhirarki dan mencakup seluruh ruang wilayah desa. 2. Pengembangan keseimbangan dan keserasian perkembangan antar wilayah antar sektor melalui terwujudnya kawasan agropolitan yang serasi dan saling mendukung serta menjamin keberlanjutan pembangunan pertanian. 3. Pengembangan kawasan lindung dan mengendalikan pemanfaatan sumber daya alam dan buatan pada kawasan lindung.

memulai kewirausahaan. Selanjutnya pengenalan wilayah kabupaten seluma Bengkulu Selatan dan khususnya desa 
Sukasari, selanjutnya membahas tentang iklim dan topografi daerah. Penjelasan ini diharapkan warga daerah memiliki pemahaman dan ilmu tentang daerah nya sendiri, dan diharapak memunculkan ide-ide kreatif warga dalam memaksimalkan potensi daerahnya.

\section{Saran}

Lapangan usaha pertanian memiliki produktifitas tenaga kerja yang rendah dan juga didominasi oleh tenaga kerja tidak dibayar (pekerja keluarga), sehingga pertumbuhan yang terjadi pada lapangan Lapangan usaha pertanian harus mendapatkan perhatian serius mengingat peranannya yang penting dalam perekonomian Kabupaten Seluma. Hal ini didasari beberapa alasan: Pertama, lapangan usaha pertanian menyerap tenaga kerja terbesar yaitu hampir 60 persen tenaga kerja terserap di lapangan usaha pertanian. Kedua, lapangan usaha pertanian dapat digunakan untuk mendukung perkembangan lapangan usaha industri dengan adanya keterkaitan
2. Pembangunan sector pertanian desa Sukasari dapat dilakukan dengan pengembangan potensi lokalnya yaitu Kelapa dan daun serai. Serta didukung dengan bagaimana melakukan pengemasan dan distribusi yang baik.

usaha ini belum mampu memberikan manfaat banyak terhadap kesejahteraan masyarakat (petani)

melalui pengembangan agroindustri bahkan agrowisata. Ketiga, komoditas ekspor andalan berupa komoditas pertanian seperti sawit dan karet merupakan sumber devisa yang diperlukan. Keempat, keberhasilan lapangan usaha pertanian dalam menciptakan pendapatan regional, menjadi sumber tabungan masyarakat untuk membiayaii investasi sehingga tidak tergantung pada sumber pendanaan luar.

\section{DAFTAR PUSTAKA}

Dimyati, A., 2007. Pembinaan Petani dan Kelembagaan Petani. Balitjeruk Online. Balai Penelitian Tanaman Jeruk dan Buah Subtropika Tlekung-Batu. Jawa Timur

Harianto (2007).Peranan Pertanian Dalam Perekonomian Pedesaan. Pusat Studi Pembangunan Pertanian dan Pedesaan, Instutut Pertanian Bogor. https://pse.litbang.pertanian.go.id/ind/pdffiles/Pros 2007-MU Harianto.pdf. Diakses tanggal 8 April 2019

Sukrino, Didik. 2012. Pembaharuan Hukum Pemerintahan Desa. Malang: Setara Press.

Purwaningsih (2008). Ketahanan Pangan: Situasi, Permasalahan, Kebijakan, dan Pemberdayaan Masyarakat. Universitas Sebelas Maret. Jurnal Ekonomi Pembangunan Vol. 9, No. 1, Juni 2008

Undang-Undang No. 6 tahun 2014 tentang Desa 